\title{
Correction to: Heteroatom-Based Compounds as Sustainable Corrosion Inhibitors: An Overview
}

\author{
Dakeshwar Kumar Verma $^{1} \cdot$ Yeestdev Dewangan ${ }^{1} \cdot$ Amit Kumar Dewangan $^{1} \cdot$ Ashish Asatkar $^{2}$
}

Published online: 3 April 2021

๑) Springer Nature Switzerland AG 2021

\section{Correction to: \\ Journal of Bio- and Tribo-Corrosion (2021) 7:15 \\ https://doi.org/10.1007/s40735-020-00447-7}

In the original online version of the article Ashish Asatkar's family name was misspelled. The original article was corrected.

Publisher's Note Springer Nature remains neutral with regard to jurisdictional claims in published maps and institutional affiliations.

The original article can be found online at https://doi.org/10.1007/ s40735-020-00447-7.

Dakeshwar Kumar Verma

dakeshwarverma@gmail.com

1 Department of Chemistry, Govt. Digvijay Autonomous

Postgraduate College, Rajnandgaon, Chhattisgarh 491441, India

2 Department of Chemistry, Govt. Gundadhur Postgraduate College, Kondagaon, Chhattisgarh, India 